\title{
The Scope of Education in the BRICS Countries as Theme for Comparative and International Education Scholarship
}

Dr Charl Wolhuter ${ }^{+*}$ and Dr Oxana Chigisheva ${ }^{*}$

\section{Abstract}

The key purpose of this study is to survey the BRICS education project, that is, education in the BRICS countries. The final objective is, fitting in the framework of this special issue, to identify the value of the epistemology that has been developed and tested by BRICS education scholars, as well as their thematic focus for the broader, global social science community. The unfolding 21st Century world and its imperatives for education are outlined. How this education-societal context is studied by the scholarly field of Comparative and International Education is then explained. The BRICS education project is then surveyed and analysed by a model which distinguishes between three dimensions of a national education project, namely the quantitative, the qualitative, and the equality dimension. It is concluded that the BRICS education project has a lot to offer in a global social science scholarship enterprise. However, to bring this promise to fruition, two recommendations are made. These are prioritisation of research on the societal outcomes of education in the BRICS countries, and that scholars in the BRICS countries should assume ownership for a scholarship of education in the BRICS countries.

Keywords: BRICS; Comparative and International Education; Education; Scholarship

\footnotetext{
${ }^{+}$Professor, Comparative and International Education, North-West University, Potchefstroom Campus, South Africa ${ }^{*}$ Corresponding Author, Email: Charl.Wolhuter@nwu.ac.za

$¥$ Associate Professor, Southern Federal University, Rostov-on-Don, Russia, Email: opchigisheva@sfedu.ru (C) 2020 Wolhuter \& Chigisheva. This is an Open Access article distributed under the terms of the Creative Commons Attribution License (http://creativecommons.org/licenses/by/2.0), which permits unrestricted use, distribution, and reproduction in any medium, provided the original work is properly cited
} 


\section{Introduction}

This article links to the lead article in this issue, which concludes that the BRICS countries offer rich soil for social sciences-research with the potential to enrich the stock of social science scholarship epistemologically (that is, the research methods used) and thematically (that is, the content or focus of research). In the BRICS societies, as elsewhere in the world, education is widely looked up to as the remedy to the entire set of societal problems besetting the world. From presenting "anti-drug education" as a remedy against the problem of drug abuse to viewing the supply of education to people as a way to bring about economic growth and the eradication of poverty and termination of unemployment, education is believed to be the answer to every societal problem. If students at all levels (from pre-primary to higher education) are included together with all the teachers, administrative, support and education management personnel, then, there are more people involved in education as their main daily activity than in any other sector in the BRICS societies. Education also constitutes a significant part of the public budget of the BRICS nations in fact, in most countries and years, the biggest single item of expenditure on public budgets. In a Special Issue on the BRICS nations, it, therefore, seems obvious to turn the spotlight to the education sector. This study aims to survey BRICS education to identify the value of BRICS education scholarship epistemology and thematic focus for the broader, global social science community. The study commences with an outline of the trends defining early $21^{\text {st }}$ Century society, and what this society is expecting of the education sector. This study falls within the scholarly field of Comparative and International Education and has been written by two scholars in that field. The concept Comparative and International Education will be clarified, and the relevance and purpose of that field of the scholarship will be elucidated in the next section. The theoretical framework for analysing and evaluating the BRICS education project will then be explained. That will be followed by an unpacking of BRICS education, employing the theoretical framework. In conclusion, the value of BRICS education scholarship for the thematic and epistemological scope in global social science research will be assessed.

\section{The Unfolding 21st Century World and its Implications for Education}

The trends defining early $21^{\text {st }}$ Century society have been outlined in the lead article of this issue. These trends will therefore not be repeated here, only how some of these trends manifest themselves in the BRICS countries, and the imperatives they direct to education.

To commence with the ecological crises, deforestation and the destruction of biological diversity are in Brazil as acutely present as in a few other countries (Myburgh, 2019). Rapid industrialisation in China and India and population pressure in all five BRICS countries, due to population size and/or swift population growth rates, place natural resources under ever more pressure and underscore the urgency of the global drive of education for sustainable development in these countries (Song, Wennersten \& Mulder, 2007, Palanichamy, 2019).

The BRICS countries are also affected by their share of the twin problems of poverty and unemployment in the world. In Table 1, the incidence of poverty and unemployment in the BRICS countries are presented.

The figures in Table 1 show that, except for Russia, the countries are severely povertystricken. And with the on-going pandemic of COVID-19, these and other countries of the world would be further pushed into poverty. At the same time, Brazil and South Africa are also affected by high levels of unemployment. 


\begin{tabular}{l|l|l|}
\hline \multicolumn{2}{|c|}{ Table 1 Incidence of Poverty and Unemployment in the BRICS countries } \\
\hline $\begin{array}{l}\text { Problem } \\
\text { Country }\end{array}$ & $\begin{array}{l}\text { Poverty } \\
\text { Percentage of Population } \\
\text { Living on less than US\$5.50 } \\
\text { per day }\end{array}$ & $\begin{array}{l}\text { Unemployment Rate } \\
\text { (Percentage of Working-age } \\
\text { Population who are } \\
\text { Unemployed) }\end{array}$ \\
\hline Brazil & 21 & 12.54 \\
\hline Russia & 2.7 & 4.74 \\
\hline India & 86.8 & 2.55 \\
\hline China & 27.2 & 4.41 \\
\hline South Africa & 57.1 & 26.95 \\
\hline Source: World Bank, 2019 & & \\
\hline
\end{tabular}

With the faith placed in education to stimulate economic growth (see: Yuan, 2011), to be a conduit for upward social mobility (see: Schleicher, 2018), and as a remedy to eradicate unemployment (see: Albright, 2017) education in the BRICS countries assumes critical importance.

The BRICS countries are all known for their startling diversity. For example, it is not widely known that, after Nigeria, Brazil is the country with the most significant number of people of African descent. Then there are significant numbers and a large variety of First Nation People in Brazil, apart from the Caucasian and Mulatto majority. India is highly diverse, ethnically-linguistically, as well as socioeconomically. The Constitution of India acknowledges 22 official languages (Modern Indian Languages) and the Constitution of China recognises 55 minorities (each with its own language). In reality, the (linguistic and ethnic) make-up in each of these two countries is even more complicated than what is suggested in their Constitutions. Russia too, even after the break-up of the Union of the Socialist Soviet Republics, is highly diverse, with minorities concentrated primarily in the peripheral regions of the country. South Africa is probably best known for its post-1994 societal reconstruction after decades, even centuries of extreme segregation policies; this reconstruction is then looked onto as a poignant object-lesson and inspiration for the rest of the world (cf. Johnson, 2019). In a world where virtually every society is characterised by increasing diversity, this diversity and its handling of education in the
BRICS countries are of interest to a global readership of scholars and the general public alike.

\section{The Scholarly Field of Comparative and International Education}

The scholarly field setting that is designed to study education systems, or teaching and learning communities, is that of Comparative and International Education. While a great diversity of views exist as to how to define exactly Comparative and International Education, for the purpose of this study, we adopt it with the meaning defined by Wolhuter, Thomas, Mashau \& Steyn (2018) as having a -three in one - perspective on education: an education system perspective, a contextual perspective and a comparative perspective.

The next logical question, after explicating the subject of study of Comparative and International Education, will obviously be; what is the significance, or value or relevance of this field of scholarly endeavour? The range of purposes has been enumerated and described by Wolhuter (2012). Here, in this study, a new (potential) relevance of the field is charted, from its study of the comparison of education in the BRICS grouping of countries, to enrich the thematic and epistemological stock of the social sciences.

\section{Theoretical Framework}

In evaluating the education effort of the BRICS countries, the theoretical model of Wolhuter (2014) will be used. The model distinguished between three dimensions of any education 
project: a quantitative dimension, a qualitative dimension, and an equality dimension. The quantitative dimension refers to participation in education. However, to expand a poor quality education to everyone is a worthless exercise. A second dimension is, therefore, quality. To clarify quality, Wolhuter (2014: 9) distinguishes between the following four components of educational quality, based on a modification of the model of Bergman (1996:581)

- Input quality: input quality refers to the quality of financial and physical (physical facilities and infrastructure) input.

- Process quality: this is the quality of teaching and learning taking place in the education project.

- Output quality: this is the outcome of the learning process, that is, the achievement levels of learners at the end of the education process.

- Product quality: product quality refers to the effect of education - or the impact thereof - which the graduated product makes. One commonly used measure of this is, for example, to calculate the rates of return to education. However, product quality covers a much more comprehensive range of individual and societal outcomes than merely individual rates of return. Typically outcomes of education formulated in response to the societal imperatives such as environmental sustainability, eradication of unemployment, eradication of poverty, stimulating economic growth, modernisation, moulding national unity, building social capital or social cohesion, strengthening democracy and the like, would be subsumed under the rubric of product quality.

The value of aggregate values or averages indicating a high quality of education - becomes restricted when a numerically small elite determines such values. Indices of quality should, therefore, be qualified by a third dimension, namely: measures of equality. A model of equal education opportunities, which is widely accepted in Comparative Education, and used by Wolhuter (2014: 10) in his model, is that of Farrell (1982: 41-47). Farrell (1982: 41-47) distinguished between four facets of equality:

- Equality of Access: the statistical chances that learners from various social categories could enter the school system.

- Equality of Survival: the statistical chances that learners from various social categories would reach a particular level in the school system (e.g. the last year of secondary school).

- Equality of Output: the statistical chances that learners from various social categories would achieve the same outcomes (e.g. pass the matriculation examination).

- Equality of Product: the statistical chances that learners from various social categories with the same educational qualifications would be able to obtain the same jobs, incomes and life opportunities.

The three-dimensional model for the evaluation of a national education project could be schematically presented, as in Figure 1.

\section{BRICS Countries in Comparative and International Education Scholarship}

The promise of the BRICS countries as a terrain for Comparative and International Education scholarship suggested by the above portrayed contextual survey does reflect in published Comparative and International Education research. Analysing the geographical foci of articles published in the first fifty years in the top journal of the field, Comparative Education Review, Wolhuter (2008: 327-328) identified the ten most frequently countries forming the focus of research, in five-year periods, and found that the BRICS countries do figure prominently. These are presented in Table 2. 


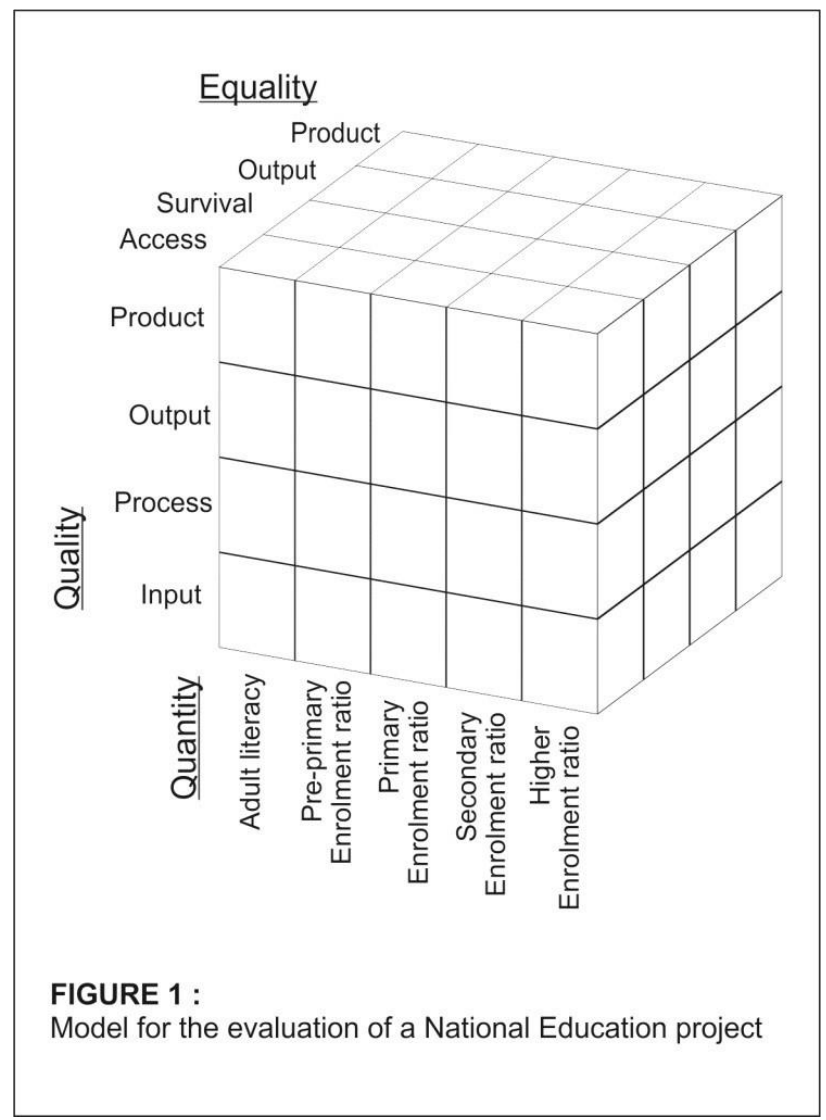

Source: Wolhuter, 2014

Table 2: BRICS Countries as Geographic Foci of Articles Published in Comparative Education Review

Volumes

BRICS Countries in Hierarchy: Rank Orders 1 to 10, of Foci of Published Articles

Volumes 1-5

Volumes 6-10

Volumes 11-15

Volumes 16-20

Volumes 21-25

Volumes 26-30

Volumes 31-35

Volumes 36-40

Volumes 41-45

Volumes 46-50
Union of the Soviet Socialist Republics: most common country South Africa: rank order number 5

China: rank order number 8

Union of the Soviet Socialist Republics: most common country

South Africa: Rank order 9

Union of the Soviet Socialist Republics: most common country

China: Rank order 4

India: Rank order 6

China: Rank order 7

China: Rank order 6

China: Rank order 2

China: Rank order 5

Brazil: Rank order 8

China: Rank order 5

Brazil: Rank order 8

China: Rank order 2

Hong Kong: Rank order 5

South Africa: Rank order 7

South Africa: the most common country

China: Rank order 3

Brazil: Rank order 8 
The Comparative Education Review commenced in 1957. The first decade and half reflected the interest, if not admiration, generated for the education system of the Union of the Socialist Soviet Republics in the United States of America (where the Comparative Education Review is based). In particular after the launch of Sputnik and when the success was attributed to the education system of the Union of the Socialist Soviet Republics (Noah, 1986: 153; Thut \& Adams, 1964: 172; Wolhuter, 2008: 327). However, as the Brezhnev era commenced and after the United States of America placed the first person on the moon in 1969, this interest waned (Wolhuter, 2008: 327). Regrettably, post1990 education reforms, such as the deideologisation of education, decentralisation, school autonomy, the effect of democratisation and the free market economy on education, the rise of the private education sector, internationalisation in higher education, and the re-appreciation of the role of religion in education, could not resuscitate interest (Wolhuter, 2008: 327).

China figured high on the research agenda ever since the outbreak of the Cultural Revolution in the mid-1960s, right through to today, having received its latest stimulus in the good performance which Shanghai schools registered in PISA (International Programme of Student Assessment) tests (Ryan, 2019:1, Wolhuter, 2008: 327). The case of India is disappointing. One reason may be that education - neither expansion of enrolments, nor reform - was for the first years after independence, for a variety of reasons, not high on the agenda of the government of independent India (Santhakumar \& Wolhuter, 2020). Furthermore, the 1944 Report of the Sargent Commission, meant to be a blueprint for post-Second World War education development in India, was severely criticised by progressive scholars and commentators for being a continuation of the colonial education project (King, 1979: 421). India only began to attract research from the international Comparative Education fraternity during the late 1960s, in the time after the restructuring of education as recommended by the Kothari Report (King, 1979: 422; Wolhuter,
2008: 327). What is striking is that notable developments in education in India have failed to attract the attention of the global scholarly community. This includes for example the Right of Children to Free and Compulsory Education Act of 2010, which introduced free and compulsory education for children between the ages of 6 to 14 years in India under Article 21A of the Indian Constitution. The achievements of universities in the frantic global universities ranking race, where they reach top notches in extra-Western contexts, have also gone largely unnoticed by the international scholarly community. The number of universities from the BRICS countries which made it to Quackuarelli Symonds (QS) 2020 list of top 1000 universities in the world, are presented in Table 3. China's remarkable feat of building universities, more so world-class universities from nothing in the post1978 era, projects such as Project 985, Project211 and the current Double World Class Universities - all very instructive for especially extra-Western societies in their quest for building world-class universities, has not attracted noteworthy scholarly attention outside China.

Brazil rose on the map after the end of the military rule in 1985 and the onset of democratisation (Wolhuter, 2008: 237). South Africa was high on the agenda till the onset of the international academic boycott in the mid1960s (see: Harricombe \& Lancaster, 1995; Hyslop, Vally \& Hassim, 2006), and re-emerged forcefully after the new socio-political and economic dispensation commenced in 1994 (Wolhuter, 2008: 327).

It should be mentioned that the survey of the volumes of the first fifty years of the Comparative Education Review corroborated a general lacuna or lopsidedness in scholarly activity in the field (Kelly, 1982: 518,519; Wolhuter, 2008). There is an over concentration dealing with how contextual forces shape education systems, and neglect of actual education systems (from education policies right down to what is taking place in schools and classrooms), and serious neglect of research on the outcomes of education ( $c f$. the product 
quality, above - to these lacuna in Comparative Education research will be returned to at the end of this study ).

The BRICS countries as a supra-national grouping have not yet commenced attracting a great deal of research from the Comparative and
International Education scholarly community. The database of the Education Resources Information Centre (ERIC) lists a mere 26 publications under the keyword "BRICS", versus, for example, 1276 under the keyword EU (ERIC, 2019).

\begin{tabular}{|c|c|}
\hline Country & $\begin{array}{l}\text { Number of Universities in the List of Top } 1000 \\
\text { Universities in the World }\end{array}$ \\
\hline Brazil & 19 \\
\hline Russia & 25 \\
\hline India & 24 \\
\hline China & 50 \\
\hline South Africa & 8 \\
\hline United States of America & 157 \\
\hline United Kingdom & 84 \\
\hline Australia & 35 \\
\hline Iran & 6 \\
\hline Turkey & 9 \\
\hline \multicolumn{2}{|c|}{$\begin{array}{l}\text { For comparison, the numbers of some of the top countries as well as two other extra- } \\
\text { Western countries are also tabled } \\
\text { Source: Quackuarelli Symonds (QS), } 2020\end{array}$} \\
\hline
\end{tabular}

\section{Assessment of the BRICS Education Effort}

\section{Quantitative Dimension}

This dimension will be assessed on the levels of adult literacy, and primary, secondary and higher education enrolments and enrolment ratios.

The World Atlas (2019) ranks 197 countries in the world according to adult literacy levels. The BRICS countries cover a wide spectrum, these together with the countries on the two extremes of the world-rankings are presented in Table 4.

The last published global analysis of the state of adult literacy and projections to the end of the present century, was that of Wolhuter \& Barbieri (2017). While adult literacy rates worldwide are on the climb, things are not as rosy when turning to absolute numbers of adult illiterates. The absolute number of illiterate adults in the world had kept on rising right up to 2010 when it began to decline. However, the rate of decrease has slowed down in recent years. A staggering 58 countries each has more than one million illiterate adults. Topping the list is India, with 256 illiterate adults, the country has the largest number of illiterate adults in the world. China has the third-largest number of illiterate adults: 41.57 million. South Africa too falls into the category of countries with more than one million illiterate adults: 2.17 million (Wolhuter \& Barbieri, 2017). Heartening is the fact that no BRICS country falls into the group of 31 countries registering at present an increase in numbers of illiterate adults (Wolhuter \& Barbieri, 2017).

Enrolments and gross enrolment ratios at primary, secondary and higher education level in the BRICS countries, according to the latest available data at the time of writing (June 2019) are presented in Tables 5 (enrolments) and 6 (enrolment ratios). 


Table: 4 Adult Literacy Rates (percentages) in BRICS Countries and Selected Other High and Low
Adult Literacy Rates Countries

Source: World Atlas (2019). List of countries by literacy levels. Retrieved on 27 October 2019 from, https://www.worldatlas.com/articles/the-highest-literacy-rates-in-the-world.html

Table 5: Enrolments in BRICS Countries at Different Levels of Education

\begin{tabular}{|l|l|l|l|l|l|}
\hline $\begin{array}{l}\text { Country } \\
\text { Level of Education }\end{array}$ & Brazil & Russia & India & China & South Africa \\
\hline Primary & 16118565 & 6198783 & 145802543 & 1003210270 & 7569924 \\
\hline Secondary & 23538072 & 9566901 & 132161359 & 83407925 & 5164481 \\
\hline Higher & 8319089 & 6182300 & 33374107 & 44127509 & 1053607 \\
\hline \multicolumn{2}{l}{ Source: UNESCO, 2019 } & & & & \\
\hline
\end{tabular}

Table 6: Gross Enrolments Ratios in BRICS Countries at Different Levels of Education (in percentages)

\begin{tabular}{|l|l|l|l|l|l|}
\hline $\begin{array}{l}\text { Country } \\
\text { Level } \\
\text { Education }\end{array}$ & Brazil & Russia & India & China & South Africa \\
\hline Primary & 113.95 & 102.08 & 114.53 & 102.05 & 102.26 \\
\hline Secondary & 101.54 & 104.81 & 75.15 & 95.03 & 100.44 \\
\hline Higher & 50.49 & 81.82 & 27.54 & 51.01 & 20.48 \\
\hline Source: UNESCO, 2019 & & & & \\
\hline
\end{tabular}

The BRICS countries can boast massive (though of course these figures should be read enrolment numbers. Gross primary education keeping in mind the inflated effect of large enrolment levels too are impressively high numbers of overage students). Ditto for 
secondary school enrolment ratios, although here the ratio for India is not high. Siddhu (2011) links low transition from primary to secondary education in India to the factors of gender, cost, and distance to schools and membership to marginalised social groups. Strines (2018) draws attention to the fact that the years of compulsory schooling in India stops at 14 , and that entrance to the upper higher secondary schools in India is very competitive. Enrolment ratios at the higher education level cover a spectrum, from Russia's 81.82 per cent, which trumps even many developed countries, to South Africa's 20.48 per cent, which is lower than that of even many developing countries. The following comparable figures from other developing countries will substantiate this point: Indonesia: 36.31 per cent, Egypt: 35.6 per cent, Morocco: 35.94 per cent, Malaysia: 45.13 per cent, and Colombia: 55.33 per cent (UNESCO, 2019).

\section{Qualitative Dimension}

A comprehensive survey of quality of education in the BRICS country in one article would be impossible. However, as an indication of where the BRICS countries lie regarding the quality of education, one indicator of input quality and a few on output quality will be focused on.

One indicator of input quality, for which data is readily available at a country level is of the number of students per teacher at the primary school level. These figures for the BRICS countries are as follows:

- Brazil: 20.32

- Russia: 20.62

- India: 35.22

- China: 16.59

- South Africa: 30.33

(UNESCO, 2019).

To interpret the above data and to place it in an international perspective: the global average number of students per teacher at primary school level is 23.64, and this figure for the various world regions ranges from 13.00 in the case of West Europe and North America to 38.50 in the case of Sub-Saharan Africa. It appears that the BRICS countries cover a range within the global spectrum.

At quality output level, in recent decades the PISA (Programme for International Student Assessment) and IEA (International Association for Evaluation of Educational Achievement) tests, which are conducted cross-nationally, have become a source for many international comparative education studies. However, when using the databases of these studies to glean an insight into the education performance of the BRICS countries, problems arise. In the case of the PISA tests, neither South Africa nor India takes part in these tests. However, in the most recent round of PISA tests (2015), Brazil, Russia and China performed as follows. Of the seventy countries that did participate, China came out tenth in the Science tests (average score of China: 523) (OECD, 2018). However, this figure is problematic, as only four provinces in China took part in the study. These four provinces, Beijing, Shanghai, Jiangsu and Guangdong, are the prime provinces in the spatial economy of China. Hence very little value can be attached to these values as representing the national average of China. Russia came out 32 nd (average score: 481 ) and Brazil 63rd out seventy (average score: 401) (OECD, 2018). While problematic, this is the best data available as China has not yet participated in an international test series with a representative country-wide sample.

Russia and South Africa participated in the 2016 PIRLS (Progress in International Reading Literacy Study), which was conducted by the IEA. Russia came out first (average score: 581) and South Africa last, that is, 50th of the fifty countries that did participate (average score: 320 ) (Mullis et al., 2016).

Results of from India are not to be found, neither in PIRLS nor in PISA. However, research investigating the geographic provenance of authorship of all articles published in all the 2012 volumes of the entire set of the Web of Science/ISI indexed journals in the field of Education, offer some idea as to the performance of the BRICS countries at this highest level of education system output, namely contribution to production of knowledge 
in top-level scholarly journals. This data is presented in Table 7.

\begin{tabular}{l|l|l|}
\hline $\begin{array}{l}\text { Table 7: Contribution of BRICS Countries to Knowledge Production } \\
\text { Indicator } \\
\text { Country }\end{array}$ & $\begin{array}{l}\text { Number of authors from Percentage of total author } \\
\text { country, in total author pool pool } \\
\text { (18523) of all authors who } \\
\text { published in all 2012 volumes } \\
\text { of all Web of Science Indexed } \\
\text { Journals in the field of } \\
\text { Education }\end{array}$ \\
\hline Brazil & 198 & 1.07 \\
\hline Russia & 10 & 0.05 \\
\hline India & 48 & 0.26 \\
\hline China & 255 & 1.37 \\
\hline South Africa & 273 & 1.47 \\
\hline Source: Wolhuter, 2017 & & \\
\hline
\end{tabular}

To interpret and to summarise, on the quality dimension the BRICS countries displays an exciting variety, not only with respect to their counts on the international spectrum of indicators but also when focusing on each single BRICS country, the quality of education differs with respect to different indicators of quality. All this underlines the value of the BRICS countries, with their interesting variegated national contexts, as thematic focus Comparative Education research.

\section{Equality Dimension}

Comparable indicators such as in the case of quality are not available in the case of education equality. It could however, be stated that the BRICS countries' education systems display their dimensions of inequality on the four levels of access, survival, outcome and product (as outlined in the theoretical model above). The universal dimensions of educational inequality are socio-economic descent, gender and race/ethnicity (the so-called trinity of educational inequality). Others include geography, age and ability. All these are present in the BRICS countries. In Russia, the chances of a person with a parent having a higher education qualification of entering higher education are 3.6 times higher than that of a person with a father who does not have a higher education qualification (Smolentseva, 2017: 221). Despite proclaiming to have created an extreme egalitarian society, all three of the trinity of educational inequality have been demonstrated to be rampantly present in the education system of the erstwhile Union of the Socialist Soviet Republics as well as in its successor states gender (Bain \& Cummings, 2000; Zakirova, 2014), socioeconomic status (Dobson \& Swafford, 1980; Broer, Bai \& Fonseca, 2019) as well as ethnic status (Krawetz, 1980; Spörlein \& Schlueter, 2018).

While admittedly dated, David Plank's (1987) study on primary school expansion in Brazil remains a classic text in Comparative Education on geographical inequalities in education along the metropolis-periphery gradient. Mathew Zachariah's (1972) publication on attempts at the equalisation of education with respect to the scheduled castes in India has been regarded as a pioneering study on policies of affirmative action (or positive discrimination) in education. This publication also illustrates the case of India regarding challenges in equalising education along the dimension of castes and socioeconomic stratification. The stature of this publication, both as research on affirmative action in education and the equalisation of education along the lines of socioeconomic disparities is clear if taken into account that Zachariah's article was included as a chapter in 
the publication Comparative Education by Altbach et al. (eds) (1982) - during the 1980s regarded as the prime orientation textbook to the field of Comparative Education. South Africa is widely hailed as the example of a society where historically education has been developed unequally along the race dimension, similarly, equalisation is one of the driving principles of the post-1994 reconstruction of education (cf. Wolhuter, 2015), and in all this South Africa is watched with passionate interest by the rest of the world (Johnson, 2019). On the other hand, Fei \& Adamson (2014) depict China's handling of ethnic diversity in China's education system as being a model worthy of following elsewhere in the world.

As was stated above, BRICS countries have not been subjected to research based on the same measures of equality. Given the value of the BRICS societal contexts as social laboratories of the world, there is a clear, compelling need for such Comparative Education research, based on the comparable data of educational equality in the different BRICS countries, and interpreting results against the backdrop of the societal contexts and education system contexts of the various BRICS countries.

\section{Conclusion}

The BRICS countries cover on all three dimensions - quantitatively, qualitatively and equality - a wide range on the global education spectrum. Given the geographic, demographic, various social and political and growing economic extent of the BRICS countries in the global pool, and given the societal contextual origin factor in the epistemological and thematic sides of social science research, BRICS education scholarship surely should have much to offer to enrich the body of social science scholarship in the world. This is not only because of the demographic, economic and geographic size of BRICS in the world, but also the societal contexts of the BRICS countries, which acutely contain features the world beyond BRICS is increasingly facing. This article, therefore, culminates with the recommendation of a call for inter-BRICS countries Comparative Education research. One particular need that can be highlighted is that education should give more attention to the societal outcomes (or product quality) of education in BRICS.

\section{References}

Altbach, P.G., Arnove, R.F. \& Kelly, G.P. (eds). (1982). Comparative Education. New York: Macmillan.

Albright, A. (2017). How education can solve the global youth unemployment crisis. Forbes 11 August 2017. Retrieved on 27 October 2019 from,

https://www.forbes.com/sites/schoolboard/20 17/08/11/how-education-can-solve-the-globalyouth-unemployment-crisis/\#136ef4533bc6

Bain, O. \& Cummings, W.K. (2000). Academe's Glass Ceiling: Societal, ProfessionalOrganizational, and Institutional Barriers to the Career Advancement of Academic Women. Comparative Education Review 44(4): 493-514.

https://www.journals.uchicago.edu/doi/abs/10 $.1086 / 447631$ ?mobileUi=0

Bergmann, H. (1996). Quality of education and the demand for education - evidence from developing countries. International Review of Education, 42(6):581-604. doi:10.1007/BF00601404.

Broer, M., Bai, Y. \& Fonseca, F. (2019).

Socioeconomic inequality and educational outcomes: an introduction. In: M Broer, Y Bai \& F Fonseca (eds) Socioeconomic Inequality and Educational Outcomes: Evidence of 20 years of TIMSS. Dordrecht: Springer: 1-6.

Dobson, R.B. \& Swafford, M. (1980). The educational attainment process in the Soviet Union: A case study. Comparative Education Review 24:252-269

https://www.jstor.org/stable/1187235

Education Resources Information Center (ERIC). Retrieved on 15 June 2019 from, https://eric.ed.gov/

Farrell, J.P. (1982). Educational Expansion and the Drive for Social Equality. In PG Altbach, RF Arnove \& GP Kelly (eds). Comparative Education. New York: Macmillan. 
Feng, A. \& Adamson, B. (2014). Trilingual Education in China: Models and challenges. Dordrecth: Springer.

Harricombe, L.J. \& Lancaster, F.W. (1995). Out in the Cold: Academic boycotts and the isolation of South Africa. Arlington: Information Resources Press.

Hyslop, J., Vally, S. \& Hassim, S. (2006). The South African Boycott Experience. Academe 92(5): 59-70.

Johnson, R.W. (2019). Fighting for the Dream. Cape Town: Jonathan Ball.

Kelly, G.P. (1982). Trends in Comparative Education. In PG Altbach, RF Arnove \& GP Kelly (eds). Comparative Education. New York: Macmillan.

King, E.J. (1979). Other Schools and Ours: Comparative Studies for Today. London: Holt, Rinehart \& Winston.

Kravetz, N. (1980). Education of Ethnic and National Minorities in the USSR: a report on current developments. Comparative Education 16(1): 13-23. www.jstor.org/stable/3098548

Mullis, I.V.S., Martin, M.O., Foy, P. \& Hooper, M. (2017). International Results: Reading PIRLS 2016. Retrieved on 31 August 2019 from, http://timssandpirls.bc.edu/pirls2016/internati onal-results/wp-

content/uploads/structure/CompletePDF/P16PIRLS-International-Results-in-Reading.pdf [Date of Access: 31 August 2019].

Myburgh, J., (2019). Speelbal van die Politici, Rapport, Rapport Weekliks, 1: 4-5.

Noah, H.J. (1986). The Use and Abuse of Comparative Education. In PG Altbach, \& GP Kelly (eds) New Approaches to Comparative Education. Chicago: The University of Chicago Press: 153-165.

OECD (2018). 2015 PISA Results in Focus. Retrieved on 27 October 2019 from, https://www.oecdilibrary.org/docserver/9789264266490en.pdf?expires $=1561005743 \& i d=i d \& a c c n a m e=g$ uest $\&$ checksum $=3$ B03A6C44A0C493B3FCE2B60 3E5B903B
Palanichamy, R.B. (2019: 16 July). India's Environmental Challenges in 10 Images. The City Fix. Retrieved on 27 October 2019 from, https://thecityfix.com/blog/indiasenvironmental-challenges-10-images-rajbhagat-palanichamy/

Phillips, D.P. and Schweisfurth, M. (2014). Comparative and International Education: An introduction to theory, method and practice (2nd edition). London: Bloomsbury.

Plank, D. (1987). The Expansion of Education: A Brazilian case study. Comparative Education Review 31(3): 361-376.

https://www.jstor.org/stable/1188570

Quacquarelli Symonds (QS). (2020). 2020

University Rankings. Retrieved on 10 April 2020 from

https://www.topuniversities.com/universityrankings/world-university-rankings/2020 .

Ryan, J. (2019). Education in China. Cambridge, UK: Polity Press.

Santhakumar, V. \& Wolhuter, C.C. (2020). Language of Learning and Teaching in South Africa and India: A comparative study In CC Wolhuter (ed.). Critical Issues in South African Education: Illumination from international comparative perspectives from the BRICS countries. Durbanville AOSIS. Forthcoming.

Schleicher, A. (2018). Equity in education: Breaking down barriers to social mobility. Paris: OECD.

Siddhu, G. (2011). Who makes it to secondary school? Determinants of transition to secondary school in India. International Journal of Educational Development 31(4): 394-401. https://doi.org/10.1016/j.ijedudev.2011.01.008

Smolentseva, A. (2017). Universal Higher Education and Positional Advantage: Soviet Legacies and neo-liberal transformations in Russia. Higher Education 73(2): 209-226. http://dx.doi.org/10.1007/s10734-016-0009-9

Song, X, Wennersten, R. \& Mulder, K. (2009). Challenges of Sustainable Development in China. Stockholm: Royal Institute of Technology. 
Spörlein, C. \& Schlueter, E. (2018) How education systems shape cross-national ethnic inequality in math competence scores: Moving beyond mean differences. PLOS ONE 13(3): e0193738.

https://doi.org/10.1371/journal.pone.0193738.

Thut, J.N. \& Adams, D. (1964). Educational

Patterns in Contemporary Societies. Tokyo: McGraw-Hull.

Trines, S. (2018). Education in India. World Education News and Reviews . Retrieved on 27 October 2019 from, https://wenr.wes.org/2018/09/education-inindi

UNESCO. 2019. Statistics.

[http://data.uis.unesco.org/] [Date of Access: 18 June 2019].

Wolhuter, C.C. (2008). Review of the Review: constructing the identity of comparative education. Research in Comparative and International Education 3(4): 323 - 344. http://dx.doi.org/10.2304/rcie.2008.3.4.323

Wolhuter, C.C. (2012). Also a door to the inside of a new house - yet another use for Comparative Education. In: Nikolay Popov, Charl Wolhuter, Bruno Leutwyler, Gillian Hilton, James Ogunleye \& Patricia Albergaria Almeida (eds). 2012. International Perspectives on Education. Sofia: Bulgarian Comparative Education Society: 23-28.

Wolhuter, C.C. (2014). Weaknesses of South African education in the mirror image of international educational development. South African Journal of Education 34(2): 1-20. DOI: 10.15700/201412071120

Wolhuter, C.C. (2015). The Case of the Education System of South Africa on the World Map: Inspiring case or call for guidance from abroad? In: C.C. Wolhuter, L. Jacobs \& HJ Steyn (eds). 2015.Thinking about Education Systems. Noordbrug: Keurkopie: 57-77.

Wolhuter, C.C. (2017). The Geography of Authorship Regarding Research in Education.
Croatian Journal of Education 19(3): 981-1000. https://doi.org/10.15516/cje.v19i3.2207

Wolhuter, C.C. (2018). The Salience of African Scholars in Education Research. Africa Education Review.

https://doi.org/10.1080/18146627.2016.12416 69

Wolhuter, C.C. \& Barbieri, N. (2017). Is the Ideal of Universal Adult Literacy in the World by the Year 2030 Statistically Attainable? Revista Internazionale Scienze Sociali 2017 (1): 87-102. https://iris.unimore.it/retrieve/handle/11380/1 157038/188673/05_Wolhuter-Barbieri.pdf

Wolhuter, C.C., Thomas, M., Mashau, T.M. \& Steyn, H.J. (2018). Comparative and International Education: A tool for powerful global impact available to South African scholars. In: Charl. C. Wolhuter (ed.). 2018. Raising the Impact of Education Research in Africa. Cape Town: AOSIS: 253-284.

World Atlas. (2019). List of countries by literacy levels. Retrieved on 27 October 2019 from, https://www.worldatlas.com/articles/thehighest-literacy-rates-in-the-world.html

World Bank (2019). Development Indicators.

Retrieved on 27 October 2019 from http://datatopics.worldbank.org/worlddevelopment-indicators/themes/poverty-andinequality.html

Yuan, S.J. (2011). Education Policies and Economic Growth in BRICs: Comparative perspectives. Knowledge Cultures 8(2): 188-197.

Zachariah, M. (1972). Positive Discrimination in Education for India's Scheduled Castes: A Review of the Problems, 1950-1970.

Comparative Education Review 16(1): 16-29. https://doi.org/10.1086/445566

Zakirova, V. (2014) Gender inequality in Russia: the perspective of participatory gender budgeting. Reproductive Health Matters. 22:44 DOI: https://doi.org/10.1016/S0968-

8080(14)44806-7 